\title{
Imagery, concreteness, goodness, and familiarity ratings for 500 proverbs sampled from the Oxford Dictionary of English Proverbs
}

\author{
JOHN BENJAFIELD, KRIS FROMMHOLD, TOM KEENAN, \\ RON MUCKENHEIM, and DIERK MUELLER \\ Brock University, St. Catharines, Ontario, Canada
}

\begin{abstract}
Partly in order to facilitate research on the relation between some standard psychological variables, we gathered normative data on 500 proverbs sampled from the Oxford Dictionary of English Proverbs (Wilson, 1970). The scales for which we gathered data are imagery, concreteness, goodness, and familiarity. These norms may be of value to researchers who wish to sample linguistic units larger than the word from a set that contains an extensive number of unfamiliar and familiar items. To illustrate the possible uses to which these data may be put, we presented a causal model of the relation between the four variables mentioned above.
\end{abstract}

Proverbs are usually regarded as a part of folk wisdom, a topic which is currently being approached with renewed interest (e.g., Bruner, 1990). Recently, there have been a number of studies of proverbs indicating an interest in their value as a tool for investigating several different psychologically interesting processes (e.g., Benjafield \& Carson, 1986; Dion, 1990; Furnham, 1987; Gergen, 1990; Honeck \& Kibler, 1984; Kemper, 1981; Rogers, 1990; Teigen, 1986). In what follows, the term proverb is being used according to its definition in the Oxford English Dictionary: "A short, pithy saying in common and recognized use ..., which is held to express some truth ascertained by experience or observation familiar to all; an adage, a wise saw." The Oxford Dictionary of English Proverbs (Wilson, 1970) makes no distinction between "proverbs, proverbial phrases and proverbial similes," and, in what follows, we have included all three.

Higbee and Millard (1983) provided imagery and familiarity norms for a set of 203 proverbs. Their goal was to facilitate "the extension of research from single words to more complex material"' (Higbee \& Millard, 1983, p. 212). Higbee and Millard report that the correlation between these two variables is .57 . However, they do not specify the procedure whereby these proverbs were selected. It is possible that a more representative sample of proverbs would reveal a different relationship between these variables. In our study, we were also interested in gathering data using additional scales. We selected two well-known measures: concreteness (e.g., Benjafield \&

Preparation of this paper was supported by a grant from the Social Sciences and Humanities Research Council of Canada to the first author. Correspondence should be addressed to J. Benjafield, Department of Psychology, Brock University, St. Catharines, Ontario L2S 3A1, Canada (e-mail:jbenjafi@spartan.ac.brocku.ca).
Muckenheim, 1989; Paivio, Yuille, \& Madigan, 1968) and goodness (Benjafield \& Muckenheim, 1989; Brown \& Ure, 1969; Rubin \& Friendly, 1986). These four scalesimagery, familiarity, concreteness, and goodness-are very widely used in psycholinguistic research. When establishing a proverb database, it is logical to first provide norms on such well known scales, thus enabling comparisons between research done with single words and research done with proverbs.

In the present study, we assembled a set of proverbs that is representative of those found in the Oxford Dictionary of Proverbs (Wilson, 1970). We selected this reference work as our source because it presents a very broad range of both familiar and unfamiliar proverbs-and not simply proverbs that are relatively well known, as in Simpson (1982). Thus, the norms we obtained should be useful to researchers who are interested in sampling proverbs that cover a broad range of familiarity, from the very uncommon or unfamiliar to the relatively common and familiar. They might also be useful to researchers who wish to sample from another database in order to replicate findings obtained in earlier studies. Researchers who are particularly interested in using a sample that is fairly representative of the range of proverbs in the written language may find our database of particular value. Our database may also be of interest to figurative language researchers. For example, norms already exist for a sample of metaphors (Katz, Paivio, \& Marschark, 1985). Proverb norms would provide another source of materials for researchers in this area, such as those reviewed by Pollio, Smith, and Pollio (1990).

After presenting a summary of the database, we will advance a causal model of the relationships between our four variables. This model will illustrate the way in which our database can be used by researchers to verify existing hypotheses and to explore new ones. 


\section{METHOD}

\section{Materials}

Our goal was to gather data on 500 proverbs. This was accomplished by randomly choosing one proverb from approximately every second page of the Oxford Dictionary of English Proverbs. From these 500,25 proverbs were randomly chosen and repeated in the database. This was done to enable reliabilities for the scales to be determined. Thus, the total number of items for which ratings were obtained was 525 .

\section{Subjects}

A total of 120 undergraduate student volunteers $(60$ men and 60 women) participated in the study. Each of the four scales described below was completed by a different group of 15 men and 15 women. By participating, the subjects fulfilled one of the requirements of the introductory psychology course at Brock University.

\section{Procedure}

All subjects were run individually, seated in front of a microcomputer terminal. The subjects were told that they would have two sessions to do all their ratings. However, because of the speed with which the subjects worked, data was typically collected in a single session of approximately $1 \mathrm{~h}$ in duration. Approximately $25 \%$ of the subjects required a second session.

\section{Presentation of Proverbs}

Each proverb was entered as a separate record in Reflex (1985), a database program. The design of the record varied, depending on the scale for which data was being collected. However, regardless of the particular scale, the subject would initially see a proverb, and below it a 7-point scale, anchored by the words defining the scale (e.g., low imagery vs. high imagery). The subject entered his/her rating for that proverb on the numeric keypad of the microcomputer, and then, by pressing one key, was shown the next record. The subject continued in this way until he/she had rated items for approximately $1 \mathrm{~h}$. If the subject did not complete all 525 ratings in the first session, they returned for the second session to complete their ratings.

The use of Reflex (1985) made it possible to present the items in a different random order to each subject. Each subject's ratings were separately recorded in Reflex. We have used Reflex previously to collect normative data (Benjafield \& Muckenheim, 1989), and a brief description of its virtues is in order here. Reflex has a design mode that allows users to place fields anywhere on the screen, enabling experimenters to create forms of virtually any design. Subjects can interact with these forms using keys or a mouse. There are also statistical formulas, including a cross-tabs facility, built into Reflex, enabling some simple summary statistics to be computed. Reflex will also export data to other programs in a variety of formats. This means, for example, that data collected in Reflex can easily be analyzed using such programs as SPSS-PC and EQS. One drawback of using Reflex is that it has no facility for obtaining reaction times.

\section{Instructions}

Except for the goodness instructions, the printed instructions given to the subjects were adapted from Toglia and Battig (1978), but modified to accommodate the different procedure and type of item. The instructions provided the subjects with a definition of a proverb, and illustrative examples, thus providing them with a context within which to make their ratings. Thus, the subjects knew that they were rating proverbs, and not simply rating sentences.

Imagery instructions. The imagery instructions were as follows:

A proverb is a concise, meaningful saying which is or once was in common recognized use. It can take the form of a sentence. like "Friends agree best at a distance," or a proverbial phrase, such as "in the nick of time.",
Proverbs differ in their capacity to arouse mental images of things or events. Some proverbs arouse a sensory experience, such as a mental picture or sound, very quickly and easily, whereas other proverbs may do so only with difficulty (i.e., after a long delay) or not at all. In this experiment you will rate a list of proverbs as to the ease or difficulty with which they arouse mental images. Any proverb that in your estimation arouses a mental image (i.e., a mental picture, or sound, or other sensory experience) very quickly and easily should be given a high imagery rating (at the upper end of the numerical scale). Any proverb that arouses a mental image with difficulty or not at all should be given a low imagery rating (at the lower end of the numerical scale).

For example, think of the saying "a fish out of water." This proverbial phrase would probably arouse an image relatively easily and would be rated as high imagery; "Honesty is the best policy" would probably do so with difficulty and be rated as low imagery.

Your ratings will be made on a 7-point scale. Feel free to use the entire range of numbers, from 1 to 7 ; at the same time, don't be concerned about how often you use a particular number as long as it is your true judgement.

After typing in a number rating, press the F8 key. Another proverb will appear on the screen, and the Rating space will clear, allowing you to type in your rating for this new proverb. The rating scale itself will remain on the screen for you to refer to.

You will be rating a total of 525 proverbs, approximately half of them today and the other half at your next session. Work fairly quickly, but do not be careless in your ratings. Take breaks if you like. If necessary, refer back to these instructions when rating the proverbs on the screen. If you'd like to know how many proverbs you've rated at any time, just let me know.

(Note: The first paragraph and the last three paragraphs of the above imagery instructions were common to all rating scales and will not be repeated below.)

Concreteness instructions. The concreteness instructions were as follows:

Proverbs differ in the extent to which they refer to concrete objects, persons, places or things that can be seen, heard, felt, smelled or tasted as contrasted with abstract concepts that cannot be experienced by our senses. In this experiment you will rate a list of proverbs with respect to their concreteness in terms of sense experience. Any proverb that refers to an abstract concept that cannot be experienced by the senses should be given a rating at the lower end of the scale. Any proverb that refers to objects, materials or persons would be given a rating at the upper end of the scale.

For example, think of the saying "a fish out of water." This proverbial phrase would probably arouse a relatively easy sensory experience, and would be rated as highly concrete. "Honesty is the best policy" would probably do so with difficulty and would be rated as abstract.

Familiarity instructions. The familiarity instructions were as follows:

Proverbs differ in their familiarity-that is, how commonly or frequently or commonly they have been experienced or how familiar they seem to be. Some proverbs are very familiar whereas others may be almost totally unfamiliar. In this experiment you will rate a list of proverbs with respect to how familiar or common they are-that is, their familiarity. Any proverb that appears very common or familiar to you should be given a high familiarity rating (at the upper end of the numerical scale). Any proverb that you are unfamiliar with, or is very new to you, should be given a low familiarity rating (at the lower end of the numerical scale). For example the saying "honesty is the best policy" is likely a very familiar saying to you and would be rated as high familiarity. "A lion's skin is not cheap" is likely less familiar and would be given a low familiarity rating.

Goodness instructions. The goodness instructions were adapted from Brown and Ure (1969). In psycholinguistic research, the term goodness traditionally refers to a scale anchored by the terms good and bad (e.g., Brown \& Ure, 1969; Rubin, 1980; Rubin \& Friendly, 
1986). The term goodness has also been used to refer to how well an item exemplifies a particular type, as in, for example, metaphor goodness (Katz, Paivio, \& Marschark, 1985). Our scale should not be confused with this second sense of goodness. The goodness instructions were as follows:

Proverbs differ in the extent to which they elicit a feeling of goodness or of badness and how intensely good or bad the feeling is. In this experiment you will rate a list of proverbs with respect to their goodness or badness. Proverbs which elicit a bad feeling should be rated with the lower numbers on the scale and those which elicit a good feeling should be rated with the higher numbers on the scale.

\section{RESULTS AND DISCUSSION}

Descriptive statistics and correlations for all variables are given in Table 1. The correlation between imagery and familiarity in our data $(r=.42)$ is lower than the value of .57 found by Higbee and Millard (1983). This difference is significant $(z=2.38, p<.05)$ and may be due either to the larger sample of proverbs or, alternatively, to the larger number of unfamiliar proverbs in our study. It is also useful to compare our norms with those obtained by Katz, Paivio, and Marschark (1985) for 204 metaphors. They found a strong correlation $(.80)$ between metaphor imageability and felt familiarity. However, their sample of metaphors was culled from anthologies of relatively well-known poets. It is possible that the correlation between these two variables would have been lower if more obscure metaphors were included in the sample. It is worth repeating Rubin's $(1980, \mathrm{p}$. 747$)$ point that the range of items examined in most psycholinguistic experiments is quite small, relative to the total possible range. The data show that our sample contains many unfamiliar proverbs, and this makes it easier to sample the entire range of proverb familiarity.

\section{Reliability}

Reliability was assessed in two ways. First, the two sets of ratings for the 25 proverbs that were repeated for each scale provided a way of assessing test-retest reliability. Each of the 25 proverbs that were repeated had two means (calculated across subjects). The two sets of means were correlated for each scale. These correlations were as follows: .87 for imagery, .92 for concreteness, .98 for goodness, and .91 for familiarity.

We also estimated reliability using the formula recommended by Tinsley and Weiss $(1975$, p. 365). The reli-

Table 1

Correlations and Descriptive Statistics for Concreteness (C), Imagery (I), Goodness (G), and Familiarity (F)

\begin{tabular}{crrrr}
\hline Variable & C & I & G & F \\
\hline C & 1.00 & & & \\
I & .65 & 1.00 & & \\
G & .30 & .35 & 1.00 & \\
F & .33 & .42 & .50 & 1.00 \\
Mean & 3.83 & 4.01 & 4.05 & 2.24 \\
SD & .85 & .90 & .75 & 1.03 \\
\hline
\end{tabular}

ability of the means given in the Appendix can be derived from a two-way analysis of variance (proverbs $\times$ raters). Reliability is given as $\left(M S_{\mathrm{p}}+M S_{\mathrm{e}}\right) / M S_{\mathrm{p}}$, where $M S_{\mathrm{p}}$ is the mean square for proverbs and $M S_{\mathrm{e}}$ is the mean square for error. The resulting values were .86 for imagery, .84 for concreteness, .86 for goodness, and .92 for familiarity.

\section{Sex Differences}

Previous studies of ratings on individual words (e.g., Benjafield \& Muckenheim, 1989; Friendly, Franklin, Hoffman, \& Rubin, 1982; Toglia \& Battig, 1978) have reported sex differences on some scales. We carried out analyses on each of our scales to see if any sex differences existed for our proverb ratings. Following the rationale given by Rubin $(1980$, p. 747), matched $t$ tests were used. (Matched $t$ tests were appropriate because we wished to generalize across proverbs, rather than across subjects.)

Mean ratings by men and women for all scales are as follows. Men gave significantly higher ratings than did women for concreteness $[M=3.95, S D=0.80$ vs. $M=$ $3.74, S D=0.88 ; t(499)=7.87, p<.001]$. However, women gave significantly higher ratings for imagery $[M=4.26, S D=1.10$ vs. $M=3.78, S D=1.01 ; t(499)$ $=9.42, p<.001]$, familiarity $[M=2.40, S D=1.19$ vs. $M=2.13, S D=1.32 ; t(499)=4.01, p<.001]$, and goodness $[M=4.18, S D=0.89$ vs. $M=3.92$, $S D=0.73 ; t(499)=9.60, p<.001]$. Benjafield and Muckenheim (1989) also found that women's imagery ratings are higher and their concreteness ratings lower than men's. Since this result appears to be consistent across item type (words vs. proverbs), further exploration of sex differences in imagery and concreteness ratings may be a good research bet (see Harshman \& Paivio, 1987).

\section{A CAUSAL MODEL}

Consider Figure 1, which presents a path diagram of the possible causal relationships between goodness, concreteness, imagery, and familiarity. This model is just determined, since there are six observed correlations between the four variables and six paths between them. The reasons for linking the variables in the ways specified in Figure 1 are as follows. One might expect goodness and familiarity to be strongly correlated because goodness and frequency of occurrence are strongly correlated in the case of single words (e.g., Boucher \& Osgood, 1969; Zajonc, 1968). The reason for such a correlation has been hotly debated (e.g., Bornstein, 1989; Zajonc, 1980, 1984). One possibility, originally proposed by Boucher and Osgood (1968), is that we try to put as good a face on things as possible, perhaps in order to advance the cause of social harmony. If we describe our surroundings positively, then we will be promoting the preservation of things as they are and avoiding social unrest or upheaval. This argument makes good sense when applied to proverbs, which may typically express socially conservative sentiments. On this 


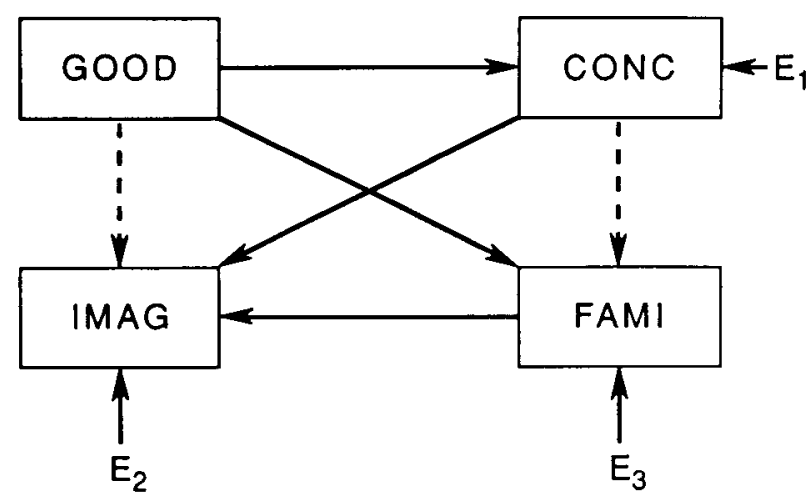

Figure 1. Causal model of the relations between goodness (GOOD), imagery (IMAG), familiarity (FAMI), and concreteness (CONC).

account, familiar proverbs would tend to refer positively to the maintenance of existing states of affairs, and warn against precipitous action (e.g., "Patience is a virtue").

There has also been considerable speculation about the relationship between goodness and imagery (e.g., Benjafield, 1983, 1987). One possibility is that people will generally be more inclined to imagine a "good" state of affairs than to imagine a "bad" one. This general tendency might result in a disposition for proverbs evaluated as good to also elicit mental images more readily (e.g., "A bird in the hand is worth two in the bush"), while proverbs evaluated as bad may elicit less imagery (e.g., "He that cannot abide a bad market deserves not a good one"). The result would be a causal path between goodness and imagery.

The model in Figure 1 also contains a path between goodness and concreteness. The rationale for such a link is similar to that for a link between goodness and imagery. Positive sentiments may be expressed using concrete, easily understood descriptions (e.g., "Stretch your arm no further than your sleeve will reach"), while there may be a tendency to express negative sentiments euphemistically in a relatively arcane way that is more difficult to grasp (e.g., "In trust is treason").

The relationship between concreteness and imagery is one of the most well established in all of psychology (e.g., Paivio, 1986; Paivio \& Begg, 1981), and we have included a path from concreteness to imagery in our model. The rationale for this link is simply that descriptions of concrete states of affairs (e.g., "A creaking door hangs long on its hinges") lead more easily to mental images than do descriptions of more abstract relationships (e.g., "An idle youth, a needy age").

Familiarity could also be a determinant of imagery. Higbee and Millard (1983) found a positive relationship between imagery and familiarity in their study of 203 proverbs. This relationship could come about simply because it may be harder to imagine unfamiliar sayings (e.g., "A holy habit cleanses not a foul soul") than familiar sayings (e.g., "You cannot eat your cake and have your cake").
Finally, concreteness might be a determinant of familiarity on the grounds that concrete proverbs (e.g., "To kill two birds with one stone") are easier to remember and consequently are used more frequently than are more abstract adages (e.g., "You will never be mad, you are of so many minds"). Additionally, the use of abstract sayings may be related to educational level, with a higher degree of literacy associated with their use (e.g., Benjafield \& Carson, 1986). This might result in abstract sayings being used only by a minority of the population, rather than attaining widespread usage.

While one can construct arguments for alternative models, the model presented above is still a plausible alternative, and it illustrates the kind of hypotheses that the present data set can be used to explore. We set about evaluating our causal model in the way recommended by Anderson and Gerbring (1988). They advised that a researcher "split a sample, using one half to develop a model and the other half to validate the solution obtained from the first half' (Anderson \& Gerbring, 1988, p. 421). Consequently, we divided our sample into two equal but randomly selected parts, each consisting of 250 proverbs. The full model given in Figure 1 was evaluated using the first set of 250 proverbs and EQS, a structural equations program (Bentler, 1989). Since the model is a justidentified one, it fits the data precisely (Loehlin, 1987, p. 65). Of the predictors of imagery, both the familiarity and concreteness coefficients are significantly different from zero $(z=4.22$ and $z=14.25$, respectively; $p<$ .001 , in both cases), but the goodness coefficient is not significant $(z=1.39)$. Of the predictors of familiarity, only goodness has a coefficient that is significantly different from zero $(z=8.14, p<.001)$, while the concreteness coefficient is not significant $(z=1.72, p>$ .05 ). Finally, goodness as a predictor of concreteness does have a coefficient that is significantly different from zero $(z=4.80, p<.001)$.

The foregoing suggests that a reduced causal model would be justified. This model would only contain those paths given in Figure 1 that are drawn using solid lines. To determine how well this reduced model works, we analyzed the second set of 250 proverbs, again using EQS (maximum likelihood method). The fit of the model to the data is only moderately satisfactory. Although the chisquare criterion (Loehlin, 1987, p. 62) allows us to reject the model $\left[\chi^{2}(2)=28.01, p<.001\right]$, several authors have noted that this is not an ideal index of goodness of model fit, since with relatively large samples a good model may still result in a significant chi-square (Loehlin, 1987, p. 67). Bentler and Bonnet's (1980) normed fit index is a measure of how well the model being tested compares with a null model in which all correlations are assumed to be zero (Loehlin, 1987, p. 68). This index has an upper limit of 1.0, which would occur if there was a perfect fit between model and data. For the reduced model, this index has a value of .90 . Bentler $(1989$, p. 93$)$ suggests that "values greater than .9 are desirable," and the present model does not quite meet that standard. Thus, 
while our model fits the data reasonably well, it is clearly not ideal. As expected, both the predictors of imageryfamiliarity and concreteness-have coefficients that are significantly different from zero $(z=4.97$ and $z=10.66$, respectively; $p<.001$, in both cases). Goodness is a significant predictor of familiarity $(z=9.30, p<.001)$; goodness is also a reliable predictor of concreteness $(z=$ $5.18, p<.001)$. These findings partially extend those of other researchers (e.g., Boucher \& Osgood, 1968; Higbee \& Millard, 1983; Paivio \& Begg, 1981) and also point to new possibilities. To our knowledge, a relationship between concreteness and goodness has not been reported before and would be worth exploring more systematically.

The multivariate analysis just presented is, of course, only a guide for future research. It is no substitute for experimental investigation, possibly using samples drawn from our norms. Moreover, researchers interested in proverbs as a form of figurative language may wish to obtain additional norms. Providing additional scales for existing norms is a practice that has been successfully established for words, as in Rubin and Friendly's (1986) supplement to the Paivio, Yuille, and Madigan (1968) norms. One task for future research might be to provide scales that are analogous to scales that have been obtained for other forms of figurative language. One such possibility is proverb aptness, which would be analogous to the metaphor aptness scale of Katz, Paivio, and Marschark (1985). Another possibility is to provide additional scales analogous to ones already existing for single words. One such example would be date of entry of a proverb into the language, which is analogous to a variable that has already been explored in relation to the psychological characteristics of single words (e.g., Benjafield \& Muckenheim, 1989). We invite other investigators to join us in this venture. Our database, including means and standard deviations for each scale for each proverb, is available on disk for MS-DOS microcomputers. Versions on 5.25 -in. $(360 \mathrm{~K}$ or $1.2 \mathrm{M})$ or 3.5 -in. $(720 \mathrm{~K}$ or $1.4 \mathrm{M})$ disks, in Reflex, ASCII, or SPSS-PC+ system file formats are available from the first author at cost. Alternatively, an e-mail listing is available by contacting jbenjafi@spartan. ac.brocku.ca.

\section{REFERENCES}

Anderson, J. C., \& Gerbring, D. W. (1988). Structural equation modeling in practice: A review and recommended two-step approach. Psychological Bulletin, 103, 411-423.

BENJAFIELD, J. (1983). Some psychological hypotheses concerning the evolution of constructs. British Joumal of Psychology, 74, 47-59.

BENJAFELD, J. (1987). An historical, social analysis of imagery and concreteness. British Journal of Social Psychology, 26, 155-164.

Benjafield, J., \& CARSON, E. (1986). The image-arousing potential of proverbs as a function of source and mode. British Journal of Social Psychology, 25, 51-56.

Benjafield, J., MuCKenheim, R. (1989). Dates-of-entry and measures of imagery, concreteness, goodness, and familiarity for 1,046 words sampled from the Oxford English Dictionary. Behavior Research Methods, Instruments, \& Computers, 21, 31-52.
Bentler, P. M. (1989). EQS: Structural equations program manual. Los Angeles, CA: BMDP Statistical Software.

Bentler, P. M., \& BonNet, D. G. (1980). Significance tests and goodness of fit in the analysis of covariance structures. Psychological Bulletin, 88, 588-606.

BoRNSTEIN, R. F. (1989). Exposure and affect: Overview and metaanalysis of research, 1968-1987. Psychological Bulletin, 106, 265-289.

Boucher, J., Oscood, C. E. (1969). The Pollyanna hypothesis. Journal of Verbal Learning \& Verbal Behavior, 8, 1-8.

Brown, W. P., \& URE, D. M. J. (1969). Five rated characteristics of 650 word association stimuli. British Journal of Psychology, 60, 232-249.

Bruner, J. S. (1990). Acts of meaning. Cambridge, MA: Harvard University Press.

Dion, K. L. (1990). Psychology and proverbs: Folk psychology revisited. Canadian Psychology, 31, 209-211.

Friendly, M., Franklin, P. E., Hoffman, D., Rubin, D. C. (1982). The Toronto Word Pool: Norms for imagery, concreteness, orthographic variables, and grammatical usage for 1,080 words. $B e$ havior Research Methods and Instrumentation, 14, 375-399.

Furnham, A. (1987). The proverbial truth: Contextually reconciling and the truthfulness of antonymous proverbs. Language \& Social Psychology, 6, 49-55.

Gergen, K. J. (1990). Proverbs, pragmatics and prediction. Canadian Psychology, 31, 212-214.

Harshman, R., \& Paivio, A. (1987). "Paradoxical" sex differences in self-reported imagery. Canadian Journal of Psychology, 41, 287-302.

Higbee, K. L., Millard, R. J. (1983). Visual imagery and familiarity ratings for 203 sayings. American Journal of Psychology, 96, 211-222.

Honeck, R. P., Kibler, C. T. (1984). The role of imagery, analogy, and instantiation in proverb comprehension. Joumal of Psycholinguistic Research, 13, 393-414.

Katz, A., Paivio, A., Marschark, M. (1985). Poetic comparisons: Psychological dimensions of metaphoric processing. Journal of Psycholinguistic Research, 14, 365-383.

KEMPER, S. (1981). Comprehension and the interpretation of proverbs. Journal of Psycholinguistic Research, 10, 179-198.

LOEHUN, J. C. (1987). Latent variable models: An introduction to factor, path and structural analysis. Hillsdale, NJ: Erlbaum.

Paivio, A. (1986). Mental representations. Oxford: Oxford University Press.

Paivio, A., \& Begg, I. (1981). Psychology of language. Englewood Cliffs, NJ: Prentice-Hall.

Paivio, A., Yuille, J., Madigan, S. (1968). Concreteness, imagery and meaningfulness values for 925 nouns. Journal of Experimental Psychology Monograph Supplement, 76(1, Pt. 2).

Pollio, H. R., Smith, M. K., Pollio, M. R. (1990). Figurative language and cognitive psychology. Language \& cognitive processes, 5, $141-167$.

Reflex [Computer program]. (1985). Scotts Valley, CA: Borland International.

Rogers, T. B. (1990). Proverbs as psychological theories.... Or is it the other way around? Canadian Psychology, 31, 195-207.

RuBIN, D. C. (1980). 51 properties of 125 words: A unit analysis of verbal behavior. Journal of Verbal Learning \& Verbal Behavior, 19 , 736-755.

Rubin, D. C., Friendly, M. (1986). Predicting which words get recalled: Measures of free recall, availability, goodness, emotionality, and pronounceability for 925 nouns. Memory \& Cognition, 14, 79-94.

Simpson, J. (1982). The concise Oxford dictionary of proverbs. Oxford: Oxford University Press.

TEIGEN, K. (1986). Old truths or fresh insights? A study of students' evaluations of proverbs. British Journal of Social Psychology, 25, 43-49.

Tinsley, H. E. A., \& WeIss, D. J. (1975). Interrater reliability and 
agreement of subjective judgments. Journal of Consulting Psychology, 22, 358-376.

Toglia, M. P., \& BATTIG, W. F. (1978). Handbook of semantic word norms. Hillsdale, NJ: Erlbaum.

WILSON, F. P. (Ed.) (1970). The Oxford dictionary of English proverbs (3rd ed.). Oxford: Oxford University Press.
Zajonc, R. B. (1968). Attitudinal effects of mere exposure. Journal of Personality \& Social Psychology Monograph, 9(2, Pt. 2), 1-28.

ZaJONC, R. B. (1980). Feeling and thinking: Preferences need no inferences. American Psychologist, 35, 151-175.

ZAJONC, R. B. (1984). On the primacy of affect. American Psychologist, 39, 117-123.

APPENDIX

Norms for Concreteness (C), Imagery (I), Goodness (G), and Familiarity (F)

\begin{tabular}{|c|c|c|c|c|}
\hline Proverb & $\mathrm{C}$ & I & $\mathrm{G}$ & $\mathbf{F}$ \\
\hline A bird in the hand is worth two in the bush & 5.03 & 5.93 & 5.27 & 5.37 \\
\hline A broken sleeve holds the arm back & 4.27 & 4.40 & 3.43 & 1.37 \\
\hline A creaking door hangs long on its hinges & 5.20 & 5.57 & 4.20 & 2.27 \\
\hline A crust is better than no bread & 5.53 & 5.90 & 5.37 & 2.70 \\
\hline A cur will bite before he bark & 4.27 & 3.43 & 3.80 & 1.70 \\
\hline A Dover shark and a Deal savage & 3.80 & 2.90 & 3.10 & 1.37 \\
\hline A friend at court & 4.00 & 3.33 & 4.10 & 2.23 \\
\hline A good archer is not known by his arrows, but his aim & 5.13 & 5.83 & 5.77 & 2.67 \\
\hline A good trencherman & 3.77 & 3.37 & 3.37 & 1.37 \\
\hline A goose cannot graze after him & 3.63 & 3.40 & 3.37 & 1.13 \\
\hline A heavy purse makes a light heart & 4.57 & 5.10 & 4.47 & 3.13 \\
\hline A holy habit cleanses not a foul soul & 2.76 & 3.57 & 4.87 & 1.73 \\
\hline A house-going parson makes a church-going people & 4.13 & 4.50 & 4.60 & 1.97 \\
\hline A leaden sword in an ivory sheath & 4.87 & 5.47 & 3.23 & 1.90 \\
\hline A liar is not believed when he speaks the truth & 4.27 & 4.40 & 5.67 & 3.80 \\
\hline A lion's skin is never cheap & 4.67 & 4.87 & 4.17 & 1.87 \\
\hline A man cannot spin and reel at the same time & 4.47 & 4.47 & 4.47 & 2.33 \\
\hline A man must plough with such oxen as he has & 5.17 & 5.13 & 4.57 & 2.17 \\
\hline A man's praise in his own mouth stinks & 3.60 & 4.53 & 4.40 & 2.83 \\
\hline A pennyworth of ease is worth a penny & 3.80 & 3.67 & 4.53 & 2.47 \\
\hline \multicolumn{5}{|l|}{ A physician is an angel when employed, but a devil } \\
\hline when one must pay him & 4.30 & 4.80 & 4.60 & 2.77 \\
\hline A pitiful mother makes a scald head & 3.03 & 3.03 & 3.20 & 1.30 \\
\hline A rolling eye, a & 4.10 & 5.17 & 4.43 & 2.87 \\
\hline A round peg in a square hole & 5.20 & 6.40 & 4.87 & 5.73 \\
\hline A short life and a merry one & 3.77 & 4.27 & 4.33 & 2.73 \\
\hline \multicolumn{5}{|l|}{ A shower in July, when the corn begins to fill, is worth } \\
\hline a plow of oxen, and all belongs there till & 4.10 & 4.37 & 3.93 & 1.30 \\
\hline of strength & 5.03 & 5.63 & 5.80 & 5.53 \\
\hline A Tyburn tippet & 2.47 & 1.97 & 2.70 & 1.20 \\
\hline \multicolumn{5}{|l|}{ A well-bred youth neither speaks of himself, nor being } \\
\hline & 4.03 & 4.10 & 4.20 & 1.93 \\
\hline A whet & 4.67 & 4.30 & 4.37 & 1.47 \\
\hline because it cannot repent & 3.03 & 3.70 & 3.60 & 1.60 \\
\hline his way & 3.33 & 4.03 & 4.53 & 2.40 \\
\hline A wise man never wants a weapon & 4.03 & 4.50 & 5.67 & 2.13 \\
\hline A woman and a glass are ever in danger & 4.07 & 4.47 & 4.03 & 1.33 \\
\hline \multicolumn{5}{|l|}{ A woman's advice is no great thing, but he who won't } \\
\hline & 3.77 & 3.43 & 5.03 & 2.33 \\
\hline A word before is worth tw & 3.10 & 3.63 & 4.83 & 2.77 \\
\hline After a delay come & 2.57 & 2.53 & 3.53 & 1.43 \\
\hline After a sort, as Costlet served the King & 2.87 & 1.93 & 3.33 & 1.23 \\
\hline Ale and history & 3.60 & 3.27 & 3.87 & 1.67 \\
\hline All Lombard Street to a China orange & 3.00 & 2.33 & 2.90 & 1.13 \\
\hline All men row galley way & 3.87 & 3.80 & 3.80 & 1.30 \\
\hline Always verify your references & 4.87 & 3.63 & 5.03 & 4.77 \\
\hline An empty purse causes a full heart & 4.37 & 4.53 & 4.27 & 2.40 \\
\hline An empty sack cannot stand upright & 5.27 & 5.50 & 4.57 & 2.30 \\
\hline An idle youth, a needy age & 3.23 & 3.50 & 3.83 & 2.07 \\
\hline An ill life, an ill end & 3.60 & 3.47 & 4.03 & 2.97 \\
\hline An old ewe dressed lamb fashion & 4.00 & 4.07 & 3.70 & 1.77 \\
\hline An owl is the king of the night & 4.90 & 5.80 & 4.47 & 2.60 \\
\hline $\begin{array}{l}\text { As a man lives, so shall he die, as a } \\
\text { it lie }\end{array}$ & 4.67 & 5.20 & 503 & \\
\hline
\end{tabular}


APPENDIX (Continued)

As dead as mutton

As fine as fivepence

As free as an ape is of his tail

As good luck as the lousy calf, that lived all winter and died in the summer

As hende as a hound in a kitchen

As honest a man as ever trod on neat's leather

As hot as a toast

As just as a square

As merry as mice in malt

As nice as a nun's hen

As playful as a kitten

As soon goes the young lamb's skin to the market as the old ewe's

As sure as the coat on one's back

At court, every one for himself

Autumnal agues are long or mortal

Be what though wouldst be called

Benefits please, like flowers, while they are fresh

Better be the head of a dog than the tail of a lion

Better go away than loathing

Better rue sit than rue flit

Between two stools one goes to the ground

Blind men can judge no colours

Blow the wind never so fast, it will fall at last

Born on the wrong side of the blanket

Butter is once a year in the cow's horn

Canterbury is the higher rack, but Winchester is the better manger

Cassandra warnings

Cast no dirt into the well that has given you water

Cats eat what hussies spare

Change of weather is the discourse of fools

Children are poor men's riches

Choose a wife on a Saturday rather than a Sunday

Common as the highway

Confess and be hanged

Conversation makes one what he is

Corn and horn go together

Crocodile tears

Deaf nuts

Desires are nourished by delays

Devonshire dumplings

Do as I say, not as I do

Do not offer salt or brains

Don't let your jaws outrun your claws

Drunken folks seldom take harm

East or west, home is best

Essex stiles, Kentish miles, Norfolk wiles, many a man beguiles

Every bean has its black

Every day comes night

Every man's censure is first moulded in his own nature

Every man's nose will not make a shoeing horn

Everything is good in its season

Experience is the mistress of fools

Fair gainings make fair spendings

Fame is but the breath of the people

Farewell, forty pence! Jack Noble is dead

Fat drops from fat flesh

Fear is stronger than love
4.13

3.27

6.37

4.97

4.37

3.33

6.03

5.57

4.20

4.33

3.37

3.17

2.97

$5.50 \quad 5.00$

$3.60 \quad 4.83$

$4.20 \quad 4.43$

3.40

4.43
5.03

6.20

5.07

4.07

4.70

5.33

4.70

3.13

2.63

2.27

3.40

$3.93 \quad 4.60$

4.37

4.67

3.20

2.60

$2.40 \quad 3.03$

$3.97 \quad 3.27$

$5.00 \quad 5.30$

$3.27 \quad 3.73$

$3.93 \quad 4.53$

3.57

3.33

2.90

2.50

2.37

1.93

5.47

5.63

$3.90 \quad 3.90$

$3.50 \quad 3.40$

4.37

3.40
4.83

$3.37 \quad 3.50$

$4.17 \quad 4.63$

$5.17 \quad 5.07$

$4.07 \quad 3.77$

$3.67 \quad 3.73$

4.90

3.13

6.03

3.13

2.67

3.30

4.07

3.80

3.73

2.70

4.77

3.77

4.60

4.57

5.20

4.27

4.87

4.53

2.83

3.73

1.80

1.47

$5.37 \quad 5.03$

$4.10 \quad 1.43$

2.97

1.30

3.40

1.17

$3.47 \quad 1.43$

$3.67 \quad 3.13$

$4.00 \quad 1.83$

$4.87 \quad 1.90$

$3.50 \quad 1.33$

$5.60 \quad 6.60$

$3.47 \quad 1.17$

$4.53 \quad 3.77$

$3.90 \quad 2.83$

$2.97 \quad 1.03$

$\begin{array}{ll}4.47 & 2.37\end{array}$

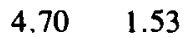

$4.07 \quad 1.70$

$4.60 \quad 2.03$

$3.20 \quad 2.03$

$4.40 \quad 1.50$

$5.13 \quad 2.13$

$\begin{array}{ll}3.63 & 2.07\end{array}$

$3.93 \quad 2.27$

$3.03 \quad 2.00$

$3.13 \quad 1.10$

$3.13 \quad 1.13$

$5.60 \quad 3.60$

$\begin{array}{ll}3.37 & 2.07\end{array}$

$3.63 \quad 1.67$

$5.03 \quad 2.23$

$3.30 \quad 2.47$

$4.03 \quad 1.83$

$4.57 \quad 2.53$

$4.77 \quad 2.60$

$3.47 \quad 1.83$

$4.07 \quad 3.40$

$2.93 \quad 3.00$

$\begin{array}{ll}4.80 & 2.37\end{array}$

$3.67 \quad 1.73$

$4.60 \quad 4.33$

$3.57 \quad 4.00$

$4.43 \quad 2.17$

$3.97 \quad 1.90$

$5.93 \quad 2.60$

$\begin{array}{llll}2.60 & 1.83 & 3.40 & 1.33\end{array}$

$\begin{array}{llll}3.93 & 2.73 & 3.67 & 1.20\end{array}$

$\begin{array}{llll}5.27 & 4.90 & 4.60 & 2.53\end{array}$

$\begin{array}{llll}3.13 & 3.93 & 4.43 & 2.63\end{array}$

$\begin{array}{llll}4.00 & 3.47 & 3.23 & 1.10\end{array}$

$\begin{array}{llll}3.60 & 4.43 & 4.87 & 2.90\end{array}$

$\begin{array}{llll}3.50 & 4.43 & 3.83 & 3.23\end{array}$

$\begin{array}{llll}3.40 & 3.53 & 4.73 & 2.23\end{array}$

$\begin{array}{llll}2.70 & 3.87 & 4.47 & 2.00\end{array}$

$\begin{array}{llll}2.77 & 3.00 & 3.00 & 1.30\end{array}$

$\begin{array}{llll}5.00 & 4.00 & 3.47 & 1.43\end{array}$

$\begin{array}{llll}4.23 & 4.97 & 3.43 & 2.60\end{array}$ 
APPENDIX (Continued)

Feed by measure and defy the physician

Fire is half bread

First up, last down

Friends tie their purse with a cobweb thread

From top to toe

Gamesters and race-horses never last long

Give a clown your finger, and he will take your hand

Give me a child for the first seven years, and you may

do what you like with him afterwards

Go fiddle for shives among old wives

God heals, and the physician has the thanks

God sends meat and the devil sends cooks

Good ware makes quick markets

Good words are good cheap

Great honours are great burdens

Gut no fish till you get them

Halcyon days

Hall benches are slippery

Happy is he that chastens himself

Hares may pull dead lions by the beard

He bestows his gifts as broom does honey

He dare not for his ears

He has gone over Asfordby Bridge backwards

He has much prayer but little devotion

He has nothing that is not contented

He has twitten a mill-post to a pudding-prick

$\mathrm{He}$ is a fool who makes his physician his heir

$\mathrm{He}$ is a velvet true heart

$\mathrm{He}$ is born in a good hour who gets a good name

He is lifeless that is faultless

$\mathrm{He}$ is like a cat; fling him which way you will, he'll light on his legs

$\mathrm{He}$ is like a rabbit, fat and lean in twenty-four hours

$\mathrm{He}$ is paced like an alderman

$\mathrm{He}$ is so hungry, he could eat a horse behind the saddle

He knows one point more than the devil

He loses nothing who keeps God for his friend

He spits on his own blanket

He stands not surely that never slips

He that cannot abide a bad market deserves not a good one

He that contemplates, has a day without night

He that does not rob makes not a robe or garment

He that does you an ill turn, will never forgive you

He that forecasts all perils will never sail the sea

He that gives thee a capon, give him the leg and wing

He that goes softly goes safely

$\mathrm{He}$ that has a white horse and a fair wife never wants trouble

He that has many friends eats too much salt with his meat

He that has the spice may season as he list

$\mathrm{He}$ that is angry is seldom at ease

$\mathrm{He}$ that is giddy thinks the world turns round

$\mathrm{He}$ that runs fastest gets the ring

He that sows good seed, shall reap good corn

He that tells a secret is another's servant

He that will be rich before night, may be hanged before noon

He that will be served must be patient

He was a bold man that first ate an oyster

He was lapped in his mother's smock

He who begins many things finishes but few

$\begin{array}{llll}3.20 & 3.10 & 3.93 & 2.30 \\ 3.17 & 3.33 & 3.60 & 1.70 \\ 3.80 & 4.10 & 4.73 & 3.07 \\ 4.03 & 4.23 & 4.57 & 3.37 \\ 5.30 & 4.97 & 4.77 & 3.63 \\ 4.33 & 5.03 & 4.13 & 3.03 \\ 4.60 & 4.57 & 4.87 & 1.80 \\ & & & \\ 4.57 & 4.77 & 3.87 & 2.10 \\ 3.17 & 3.77 & 3.13 & 2.33 \\ 3.80 & 3.80 & 4.90 & 2.60 \\ 3.93 & 4.17 & 4.03 & 2.30 \\ 3.57 & 3.97 & 4.40 & 1.60 \\ 2.97 & 3.67 & 4.27 & 2.27 \\ 3.23 & 3.27 & 4.83 & 2.20 \\ 5.23 & 4.47 & 4.37 & 2.73 \\ 2.30 & 3.87 & 3.40 & 1.43 \\ 5.00 & 2.80 & 3.50 & 1.47 \\ 3.33 & 3.73 & 4.60 & 1.53 \\ 4.30 & 3.50 & 3.77 & 1.77 \\ 3.63 & 4.00 & 3.23 & 1.47 \\ 3.47 & 3.17 & 3.53 & 1.30 \\ 3.97 & 2.67 & 3.17 & 1.43 \\ 3.87 & 3.80 & 4.23 & 1.73 \\ 2.70 & 3.70 & 4.17 & 2.70 \\ 2.47 & 2.87 & 3.07 & 1.37 \\ 3.63 & 4.07 & 4.17 & 1.80 \\ 3.97 & 3.27 & 4.40 & 2.03 \\ 3.03 & 4.07 & 3.93 & 1.80 \\ 4.17 & 4.77 & 3.67 & 1.83 \\ & & & \\ 3.67 & 3.27 & 4.97 & 2.27 \\ 5.13 & 4.17 & 4.53 & 2.80 \\ 3.33 & 4.10 & 2.97 & 1.17 \\ 4.87 & 4.07 & 4.10 & 2.70 \\ 3.13 & 4.10 & 4.23 & 2.50 \\ 3.47 & 3.73 & 5.43 & 1.97 \\ 4.83 & 4.17 & 3.27 & 2.60 \\ 3.77 & 4.67 & 3.93 & 1.60 \\ & & & \\ 3.20 & 3.07 & 3.33 & 2.03 \\ 3.30 & 3.37 & 3.30 & 1.57 \\ 3.33 & 3.30 & 4.07 & 1.40 \\ 3.43 & 3.60 & 4.37 & 1.67 \\ 3.50 & 3.20 & 3.77 & 1.77 \\ 3.77 & 3.80 & 3.90 & 2.20 \\ 4.63 & 4.57 & 3.13 & 1.77 \\ & & & \\ 3.70 & 4.10 & 4.80 & 2.20 \\ & & & \\ 3.80 & 4.33 & 4.70 & 3.60 \\ 3.90 & 4.70 & 5.07 & 2.33 \\ 4.00 & 3.77 & 4.93 & 2.13 \\ 4.03 & 3.27 & 5.10 & 1.93 \\ 4.13 & 3.67 & 4.07 & 1.57 \\ 4.13 & 4.47 & 4.57 & 2.00 \\ 4.23 & 4.17 & 4.37 & 2.97 \\ & & & \\ 5.43 & 4.97 & 5.60 & 2.27 \\ 5.53 & 4.70 & 4.87 & 2.37 \\ 4.83 & 4.97 & 4.97 & 3.40 \\ 4.27 & 4.93 & 3.53 & 1.40 \\ 4.30 & 5.23 & 4.53 & 2.51\end{array}$


He who plants a walnut tree expects not to eat of the fruit

He who will stop every man's mouth must have a great deal of meal

He will not part with the paring of his nails

He will swear dagger out of sheath

Hear and see and say nothing

Hell is broke loose

Hertfordshire clubs and clouted shoon

His heart is in his heels

His hobby runs away with him

Hold him to it buckle and thong

Hope keeps man alive

Hot love, hasty vengeance

Hunger is good kitchen meat

I am the worst carver in the world: I should never make a good chaplain

I have lived too near a wood to be frightened by owls

I would cheat mine own father at cards

If grass look green in Janiveer, 'twill look the worser all the year

If the doctor cures, the sun sees it; but if he kills, the earth hides it

If thou thyself canst do it, attend no other's help or hand

If we buy the devil, we must sell the devil

If you beat spice it will smell the sweeter

If you bleed your nag on St. Steven's day, he'll work your work for ever and aye

If you cannot bite, never show your teeth

If youth knew what age would crave, it would both get and save

In rain and sunshine, cuckolds go to heaven

In the old of the moon, a cloudy morning bodes a fair afternoon

In the twinkling of an eye

In trust is treason

In war it is not permitted twice to err

Indian summer

Is Saul also among the prophets?

It early pricks that will be a thorn

It is a bad cause that none dare speak in

It is a hard winter when one wolf eats another

It is a silly fish that is caught twice with the same bait

It is an ill bird that bewrays its own nest

It is an ill sign to see a fox lick a lamb

It is an ill wind that blows nobody good

It is better driving a flock than one

It is better to sup with a cutty than want a spoon

It is good to have a cloak for the rain

It is misery enough to have once been happy

It is no sure rule to fish with a cross-bow

It is not as thy mother says, but as thy neighbours say

It is nuts to him

It is the fairest flower in his crown

It will all come right in the wash

It would have made a horse laugh

Itch and ease can no man please

Jack of all trades

John-a-droyne

Keep the staff in your own hand

Kentish cousins

Keystone under the hearth, keystone under the horse's belly

\begin{tabular}{|c|c|c|c|}
\hline 4.50 & 4.10 & 4.20 & 2.17 \\
\hline 3.54 & 4.53 & 4.20 & 1.87 \\
\hline 3.53 & 4.20 & 2.90 & 1.33 \\
\hline 3.87 & 3.70 & 3.43 & 1.70 \\
\hline 4.57 & 4.30 & 4.57 & 2.5 \\
\hline 4.07 & 4.77 & 4.17 & 5.3 \\
\hline 2.73 & 3.47 & 3.03 & 3.5 \\
\hline 4.40 & 3.37 & 3.77 & 1.63 \\
\hline 3.33 & 4.53 & 4.07 & 2.87 \\
\hline 4.00 & 3.57 & 3.67 & 1.7 \\
\hline 3.63 & 4.20 & 5.97 & 2.87 \\
\hline 3.30 & 4.20 & 4.43 & 3.3 \\
\hline 4.13 & 3.90 & 4.07 & 1.73 \\
\hline 3.27 & 3.60 & 3.10 & 1.23 \\
\hline 4.90 & 3.90 & 4.80 & 1.50 \\
\hline 4.83 & 4.73 & 2.60 & 2.9 \\
\hline 4.20 & 4.40 & 3.60 & 1.6 \\
\hline 4.4 & 4.20 & 4.43 & 1.77 \\
\hline 3.63 & 4.07 & 3.83 & 1.67 \\
\hline 2.63 & 3.57 & 4.03 & 1.47 \\
\hline 3.07 & 4.07 & 3.20 & 1.5 \\
\hline 4.37 & 3.97 & 4.23 & 2.00 \\
\hline 532 & 4.23 & 4.77 & 1.77 \\
\hline 3.27 & 4.13 & 4.70 & 2.07 \\
\hline 370 & 2.97 & 3.70 & 1.17 \\
\hline 4.13 & 4.00 & 4.23 & 1.47 \\
\hline 4.70 & 5.30 & 5.43 & 3.50 \\
\hline 2.60 & 4.77 & 3.67 & 4.47 \\
\hline 4.20 & 3.83 & 4.50 & 2.27 \\
\hline 4.77 & 4.90 & 4.93 & 4.40 \\
\hline 3.53 & 3.87 & 3.47 & 3.87 \\
\hline 4.3 & 3.67 & 3.70 & 1.43 \\
\hline 3.00 & 3.57 & 4.00 & 1.7 \\
\hline 4.73 & 4.23 & 4.33 & 1.63 \\
\hline 5.40 & 5.70 & 5.60 & 3.6 \\
\hline 4.13 & 5.23 & 3.97 & 2.13 \\
\hline 5.00 & 5.20 & 3.53 & 1.4 \\
\hline 3.43 & 5.03 & 4.17 & 2.47 \\
\hline 3.37 & 3.87 & 3.47 & 1.13 \\
\hline 3.77 & 4.33 & 4.43 & 2.20 \\
\hline 5.73 & 4.00 & 4.70 & 1.60 \\
\hline 3.40 & 5.13 & 3.93 & 2.30 \\
\hline 3.43 & 3.87 & 3.97 & 1.30 \\
\hline 4.37 & 4.20 & 3.93 & 1.83 \\
\hline 3.67 & 3.43 & 3.17 & 1.9 \\
\hline 4.30 & 3.87 & 4.43 & 2.13 \\
\hline 3.70 & 4.20 & 5.20 & 3.57 \\
\hline 3.73 & 4.80 & 4.07 & 3.57 \\
\hline 3.80 & 4.87 & 4.00 & 2.27 \\
\hline 4.73 & 4.67 & 5.73 & 4.40 \\
\hline 1.97 & 3.07 & 2.80 & 3.67 \\
\hline 4.80 & 2.83 & 4.60 & 1.37 \\
\hline 3.17 & 3.63 & 3.13 & 1.50 \\
\hline & 2.93 & 3.23 & 1. \\
\hline
\end{tabular}


APPENDIX (Continued)

Kindness lies not aye in one side of the house

Lay up against a rainy day

Lend and lose; so play fools

Let all live as they would die

Let him that pays the lawing choose the lodging

Let one devil ding another

Letters of Bellerophon

Like carpenter, like chips

Like it, or lump it

Lincolnshire, where hogs shit soap, and cows shit fire

Little good comes of gathering

Little wealth little care

Long be thy legs and short be thy life

Lose nothing for asking

Love is blind

Love your friend with his fault

Maidens should be meek till they be married

Make not the gate wider than the city

Make or mar

Make your enemy your friend

Many strokes fell great oaks

March dust and May sun, makes corn white and maids dun

Marriage is destiny

Married man turns his staff into a stake

Marry not an old crony, or a fool, for money

Measure is a merry mean

Men are not angels

Metal upon metal is false heraldry

Modesty sets off one newly come to honour

Money refused loses its brightness

Muckson up to the buckson

Mute as a fish

My mind to me a kingdom is

Nature is conquered by obeying her

Necessity and opportunity may make a coward valiant

Never refuse a good offer

Never too late to mend

No case: abuse the plaintiff's attorney

No extreme will hold long

No folly to being in love

No man can be a good ruler unless he has first been ruled

No man is a hero to his valet

No pains, no gains

No tempest, good July, lest corn look ruely

Not only ought fortune to be pictured on a wheel, but every thing else in the world

Not worth a louse

Nothing so certain as death

Obedience is much more seen in little things than in great

Oil of fool

Old sin makes new shame

On Candlemas Day, throw the candle and candlestick away

$\begin{array}{llll}2.93 & 2.93 & 3.57 & 1.37\end{array}$

$\begin{array}{llll}3.60 & 3.07 & 4.40 & 2.77\end{array}$

$\begin{array}{llll}2.90 & 3.50 & 4.17 & 2.50\end{array}$

$\begin{array}{llll}3.17 & 3.93 & 4.80 & 2.33\end{array}$

$\begin{array}{llll}3.60 & 3.67 & 3.80 & 2.60\end{array}$

$\begin{array}{llll}3.77 & 3.40 & 3.63 & 1.27\end{array}$

$\begin{array}{llll}2.67 & 3.10 & 3.03 & 1.77\end{array}$

$\begin{array}{llll}3.90 & 3.20 & 3.70 & 1.57\end{array}$

$\begin{array}{llll}3.87 & 3.67 & 5.03 & 4.07\end{array}$

$\begin{array}{llll}3.77 & 4.73 & 2.67 & 3.50\end{array}$

$\begin{array}{llll}3.50 & 3.83 & 3.53 & 1.50\end{array}$

$\begin{array}{llll}3.53 & 4.33 & 3.60 & 2.43\end{array}$

$\begin{array}{llll}3.70 & 3.87 & 3.30 & 1.57\end{array}$

$\begin{array}{llll}3.50 & 4.23 & 5.37 & 3.17\end{array}$

$\begin{array}{llll}3.70 & 4.50 & 5.53 & 5.47\end{array}$

$\begin{array}{llll}3.87 & 4.37 & 5.83 & 5.03\end{array}$

$\begin{array}{llll}4.10 & 4.07 & 3.30 & 2.30\end{array}$

$\begin{array}{llll}4.23 & 4.93 & 4.30 & 2.37\end{array}$

$\begin{array}{llll}2.70 & 3.97 & 3.83 & 1.90\end{array}$

$\begin{array}{llll}3.93 & 2.97 & 5.30 & 3.07\end{array}$

$\begin{array}{llll}5.07 & 4.53 & 4.30 & 3.73\end{array}$

$\begin{array}{llll}4.37 & 4.23 & 3.40 & 1.63\end{array}$

$\begin{array}{llll}2.97 & 4.03 & 4.17 & 1.67\end{array}$

$\begin{array}{llll}3.63 & 3.77 & 3.50 & 1.90\end{array}$

$\begin{array}{llll}4.37 & 4.60 & 5.07 & 1.93\end{array}$

$\begin{array}{llll}2.97 & 3.83 & 3.63 & 2.33\end{array}$

$\begin{array}{llll}4.63 & 4.97 & 4.63 & 3.37\end{array}$

$\begin{array}{llll}3.37 & 4.23 & 3.60 & 2.17\end{array}$

$\begin{array}{llll}2.63 & 3.50 & 3.77 & 1.60\end{array}$

$\begin{array}{llll}3.37 & 3.60 & 4.33 & 1.80\end{array}$

$\begin{array}{llll}2.33 & 3.10 & 3.13 & 1.73\end{array}$

$\begin{array}{llll}4.97 & 3.37 & 3.60 & 1.17\end{array}$

$\begin{array}{llll}3.57 & 5.13 & 5.13 & 2.07\end{array}$

$\begin{array}{llll}3.03 & 3.83 & 4.73 & 2.30\end{array}$

$\begin{array}{llll}3.37 & 3.67 & 4.77 & 1.93\end{array}$

$\begin{array}{llll}3.97 & 3.67 & 5.33 & 3.17\end{array}$

$\begin{array}{llll}3.77 & 3.67 & 5.47 & 4.50\end{array}$

$\begin{array}{llll}3.60 & 2.87 & 3.63 & 3.43\end{array}$

$\begin{array}{llll}2.87 & 2.93 & 4.70 & 1.90\end{array}$

$\begin{array}{llll}2.90 & 3.17 & 4.43 & 2.03\end{array}$

$\begin{array}{llll}4.17 & 3.67 & 5.50 & 3.23\end{array}$

$\begin{array}{llll}3.77 & 3.57 & 4.13 & 2.50\end{array}$

$\begin{array}{llll}4.90 & 4.63 & 5.77 & 4.23\end{array}$

$\begin{array}{llll}3.17 & 3.57 & 3.30 & 3.83\end{array}$

$\begin{array}{llll}3.23 & 2.77 & 3.93 & 1.37\end{array}$

$\begin{array}{llll}3.47 & 3.60 & 3.50 & 1.57\end{array}$

$\begin{array}{llll}4.67 & 4.57 & 5.07 & 3.77\end{array}$

$\begin{array}{llll}3.37 & 4.07 & 4.80 & 2.60\end{array}$

$\begin{array}{llll}2.83 & 3.30 & 2.70 & 1.97\end{array}$

$\begin{array}{llll}3.27 & 3.47 & 4.23 & 1.87\end{array}$

$\begin{array}{llll}3.83 & 3.27 & 3.37 & 1.50\end{array}$

$\begin{array}{llll}4.23 & 4.13 & 4.37 & 1.13\end{array}$

$\begin{array}{llll}4.53 & 3.73 & 4.13 & 2.27\end{array}$

One barber shaves another gratis

One can go a long way after one is weary

$\begin{array}{llll}3.73 & 4.07 & 4.57 & 2.00\end{array}$

One foot is better than two crutches

One is not smelt where ali stink

$\begin{array}{llll}4.90 & 4.70 & 4.80 & 2.03\end{array}$

One mend-fault is worth twenty spy-faults

$\begin{array}{llll}4.53 & 5.57 & 4.63 & 3.00\end{array}$

$\begin{array}{llll}2.50 & 3.48 & 3.37 & 1.37\end{array}$ 
APPENDIX (Continued)

One mouth does nothing without another

One's too few, three too many

Other times, other manners

Out of the peat-pot into the mire

Over covetous was never good

Past cure, past care

Patience is a virtue

Pigs love that lie together

Please your eye and plague your heart

Praise a hill, but keep below

Pride breakfasted with plenty, dined with poverty, and supped with infamy

Princes have no way

Prosperity is the blessing of the Old Testament, adversity the blessing of the new

Providence is better than rent

Punctuality is the soul of business

Put off the evil hour as long as you can

Quality, without quality, is little thought of

Queen's weather

Raw head and bloody bone

Render unto Caesar the things which are Caesar's

Respect a man, he will do the more

Ring of Gyges

Ross was, Dublin is, Drogheda shall be

Safety first

Saturday's new, and Sunday's full, was never fine and never wool

Say well or be still

Self-preservation is the first law of nature

She is a good maid, but for thought, word, and deed

She is meat for your master

Shear sheep that have them

Sift him grain by grain and he proves but chaff

Six of one and half a dozen of the other

Sleep is the image of death

Sloth, like rust, consumes faster than labour wears

So got, so gone

Somerton ending

Sorrow to his sops

St. Andrew the King, three weeks and three days before

Christmas comes in

St. Matthie sends saps into the tree

Stafford law

Sticking goes not by strength, but by guiding of the gully

Straight as a line

Stretch your arm no further than your sleeve will reach

Suits hang half a year in Westminster Hall; at Tyburn, half an hour's hanging endeth all

Sutton for mutton, Kirby for beef, South Darne for gingerbread, Dartford for a thief

Sweet as a nut

Swine, women and bees cannot be turned

Tailor-like

Take away fuel, take away flame

Take no more on you than you're able to bear

Take time when time comes

Tales of Robin Hood are good among fools

Teach your grandmother to suck eggs

That calf never heard church-bell

That penny is well-spent that saves a groat

That which is good for the back, is bad for the head

\begin{tabular}{|c|c|c|c|}
\hline 4.37 & 4.47 & 4.73 & 1.80 \\
\hline 3.90 & 4.27 & 4.73 & 3.23 \\
\hline 2.57 & 3.67 & 4.33 & 2.80 \\
\hline 4.17 & 3.50 & 3.63 & 2.77 \\
\hline 2.77 & 2.60 & 4.07 & 1.80 \\
\hline 3.30 & 2.50 & 3.90 & 2.40 \\
\hline 2.93 & 4.10 & 6.47 & 4.97 \\
\hline 3.67 & 3.83 & 3.40 & 3.93 \\
\hline 3.73 & 4.83 & 4.77 & 2.47 \\
\hline 3.17 & 3.87 & 3.77 & 2.00 \\
\hline 2.60 & 3.93 & 4.47 & 1.37 \\
\hline 2.53 & 2.70 & 3.07 & 1.63 \\
\hline 3.27 & 3.13 & 4.70 & 1.77 \\
\hline 2.60 & 2.87 & 3.57 & 1.73 \\
\hline 3.60 & 3.10 & 5.23 & 2.33 \\
\hline 2.33 & 3.93 & 4.27 & 2.37 \\
\hline 2.40 & 3.10 & 4.43 & 1.67 \\
\hline 3.00 & 2.63 & 3.03 & 1.87 \\
\hline 4.53 & 4.23 & 2.70 & 1.20 \\
\hline 3.97 & 5.03 & 4.80 & 3.00 \\
\hline 3.77 & 3.37 & 5.63 & 3.00 \\
\hline 3.27 & 3.03 & 2.80 & 1.83 \\
\hline 2.83 & 2.53 & 3.37 & 1.07 \\
\hline 4.43 & 2.60 & 5.33 & 3.77 \\
\hline 2.80 & 3.33 & 3.60 & 3.57 \\
\hline 3.43 & 2.87 & 4.77 & 2.03 \\
\hline 3.67 & 3.50 & 5.33 & 3.00 \\
\hline 4.10 & 3.80 & 3.50 & 2.30 \\
\hline 3.73 & 4.40 & 2.83 & 1.87 \\
\hline 4.03 & 4.13 & 3.67 & 1.80 \\
\hline 3.97 & 3.93 & 4.17 & 1.77 \\
\hline 4.17 & 4.13 & 5.33 & 3.53 \\
\hline 4.37 & 4.77 & 3.70 & 3.63 \\
\hline 3.70 & 4.23 & 4.00 & 2.20 \\
\hline 2.57 & 3.00 & 4.17 & 2.37 \\
\hline 2.07 & 1.63 & 2.97 & 2.10 \\
\hline 2.47 & 2.17 & 3.03 & 1.10 \\
\hline 2.90 & 2.27 & 3.30 & 1.27 \\
\hline 3.67 & 3.10 & 3.20 & 1.07 \\
\hline 2.57 & 2.93 & 3.20 & 1.23 \\
\hline 2.57 & 2.43 & 3.47 & 1.20 \\
\hline 6.03 & 3.97 & 5.13 & 2.57 \\
\hline 5.63 & 6.23 & 5.00 & 3.83 \\
\hline 3.43 & 4.43 & 3.17 & 1.77 \\
\hline 3.63 & 3.13 & 3.27 & 1.30 \\
\hline 4.67 & 3.57 & 3.47 & 1.20 \\
\hline 4.40 & 4.57 & 3.47 & 2.17 \\
\hline 3.53 & 3.93 & 3.63 & 1.37 \\
\hline 5.30 & 4.73 & 4.77 & 3.07 \\
\hline 4.13 & 4.87 & 5.20 & 3.33 \\
\hline 3.20 & 3.70 & 5.33 & 3.33 \\
\hline 3.73 & 3.70 & 3.20 & 2.13 \\
\hline 4.50 & 5.37 & 2.47 & 1.67 \\
\hline 4.00 & 4.23 & 3.07 & 1.30 \\
\hline 4.23 & 3.23 & 4.37 & 1.40 \\
\hline 4.53 & 3.43 & 3.90 & 1.83 \\
\hline
\end{tabular}




\section{APPENDIX (Continued)}

The best is as good as stark naught

The Bishop has put his foot in it

The black ox has trod on his foot

The boot is on the other leg

The bride goes to her marriage-bed, but knows not what shall happen to her

The cat sees not the mouse ever

The citizen is at his business before he rise

The cowl does not make the monk

The dainties of the great are tears of the poor

The date is out

The day of France's ruin is the eve of the ruin of England

The death of the wolves is the safety of the sheep

The ducks fare well in the Thames

The dust raised by the sheep does not choke the wolf

The ebb will fetch off what the tide brings in

The Englishman Italianate is devil incarnate

The face is the index of the heart

The first cock of hay, frights the cuckoo away

The goat must browse where she is tied

The grace of a gray bannock is in the baking of it

The greater the man the greater the crime

The grief of the head is the grief of griefs

The highest branch is not the safest roost

The hindmost dog may catch the hare

The joy of the heart makes the face fair

The law is an ass

The longer forenoon, the shorter afternoon

The merry month of May

The mill gets by going

The moon is not seen where the sun shines

The more thy years, the nearer thy grave

The poor man turns his cake, and another comes and

takes it

The post of honour is the post of danger

The schoolmaster is abroad

The second side of the bread takes less time to toast

The shoe will hold with the sole

The spear of Achilles could both wound and heal

The unsonsy fish aye gets the unlucky bait

The vale best discovers the hill

The weaker has the worse

The wise hand does not all that the foolish mouth speaks

The world is a wide parish

There are three ways: the church, the sea, the court

There is a time for all things

There is chance in the cock's spur

There is more victuals in England than in seven other kingdoms

There is no difference of bloods in a basin

There is no pain like the gout

There is no such flatterer as a man's self

There is no virtue that poverty destroys not

There leaped a haddock

There were brave men before Agamemnon

They are well guided that God guides

They cleave together like burrs

They have need of a blessing who kneel to a thistle

They love me for little that hate me for naught

They may sit in the chair that have malt to sell

They that see you in daylight winna break the house for you at night

\begin{tabular}{|c|c|c|c|}
\hline 2.53 & 2.90 & 3.37 & 1.67 \\
\hline 3.73 & 3.33 & 3.47 & 1.67 \\
\hline 4.13 & 4.77 & 3.00 & 1.53 \\
\hline 5.67 & 5.63 & 4.07 & 3.10 \\
\hline 4.40 & 5.33 & 3.57 & 2.20 \\
\hline 4.73 & 4.97 & 3.43 & 1.73 \\
\hline 3.00 & 4.43 & 3.50 & 1.93 \\
\hline 3.37 & 3.23 & 4.27 & 1.23 \\
\hline 3.37 & 3.50 & 4.03 & 1.43 \\
\hline 3.20 & 2.57 & 3.03 & 2.80 \\
\hline 3.47 & 3.37 & 3.50 & 1.93 \\
\hline 4.87 & 5.33 & 4.70 & 1.60 \\
\hline 4.37 & 4.57 & 3.50 & 1.90 \\
\hline 4.60 & 5.60 & 4.17 & 1.30 \\
\hline 3.70 & 4.20 & 4.73 & 1.90 \\
\hline 2.93 & 2.93 & 3.03 & 1.67 \\
\hline 4.37 & 5.20 & 5.07 & 2.40 \\
\hline 3.83 & 3.00 & 3.27 & 1.70 \\
\hline 5.27 & 5.23 & 4.20 & 1.30 \\
\hline 3.13 & 2.80 & 3.70 & 1.27 \\
\hline 3.57 & 4.27 & 3.67 & 2.10 \\
\hline 2.97 & 2.63 & 4.03 & 2.10 \\
\hline 4.83 & 5.73 & 5.37 & 1.87 \\
\hline 4.23 & 4.70 & 4.53 & 1.87 \\
\hline 4.33 & 4.33 & 5.33 & 1.83 \\
\hline 3.60 & 4.20 & 3.83 & 1.97 \\
\hline 3.30 & 3.47 & 4.37 & 1.40 \\
\hline 3.00 & 4.50 & 4.63 & 3.90 \\
\hline 3.57 & 3.17 & 4.03 & 3.77 \\
\hline 5.83 & 5.33 & 4.97 & 1.77 \\
\hline 4.47 & 4.90 & 4.43 & 2.93 \\
\hline 4.27 & 4.63 & 3.40 & 2.13 \\
\hline 3.53 & 3.73 & 4.13 & 2.00 \\
\hline 4.40 & 3.97 & 3.33 & 1.27 \\
\hline 5.10 & 5.43 & 4.27 & 2.20 \\
\hline 4.63 & 5.20 & 4.37 & 1.93 \\
\hline 4.30 & 4.97 & 4.33 & 1.73 \\
\hline 4.27 & 4.00 & 3.67 & 1.97 \\
\hline 3.53 & 3.50 & 3.37 & 1.17 \\
\hline 2.70 & 3.13 & 3.67 & 1.30 \\
\hline 4.00 & 4.07 & 5.03 & 2.13 \\
\hline 3.57 & 4.67 & 4.10 & 1.67 \\
\hline 4.43 & 3.83 & 4.07 & 1.47 \\
\hline 2.83 & 3.50 & 4.37 & 2.23 \\
\hline 3.23 & 2.67 & 3.23 & 3.70 \\
\hline 3.47 & 2.87 & 3.60 & 1.30 \\
\hline 4.23 & 4.67 & 3.73 & 1.97 \\
\hline 4.83 & 3.80 & 3.40 & 1.70 \\
\hline 3.73 & 4.30 & 4.40 & 2.37 \\
\hline 3.93 & 3.77 & 5.50 & 3.97 \\
\hline 4.20 & 4.23 & 3.73 & 1.70 \\
\hline 4.10 & 2.73 & 3.80 & 1.30 \\
\hline 3.13 & 3.57 & 5.40 & 1.93 \\
\hline 5.17 & 4.90 & 4.37 & 2.20 \\
\hline 3.43 & 3.37 & 3.50 & 1.53 \\
\hline 2.70 & 3.13 & 4.47 & 1.53 \\
\hline 3.60 & 3.30 & 3.13 & 1.17 \\
\hline .0 & 2.63 & 4.47 & 1.73 \\
\hline
\end{tabular}


APPENDIX (Continued)

They that think none ill are soonest beguiled

Thieves and rogues have the best luck, if they do but scape hanging

Thou singest like a bird called a swine

Three dear years will raise a baker's daughter to a portion

Throw him into the Nile and he will come up with a fish in his mouth

To add insult to injury

To agree like cats and dogs

To be beforehand with the world

To be in the suds

To be on the war-path

To be ready to burst with laughing

To be taken in one's own net

To be wedded to one's will

To be worth one's salt

To bring one's bow

To burst at the broadside

To couch a hogshead

To cut off one's nose to spite one's face

To dance the shaking of the sheets

To dress an egg and give the offal to the poor

To fling one's handkerchief

To flog a dead horse

To foam like a boar

To fret one's self to fiddlestrings

To give one a recumbentibus

To give one the bag to hold

To give the cold shoulder

To go to Bedfordshire

To hang a nose

To have a man's head under one's girdle

To have the right sow by the ear

To kill two birds with one stone

To kiss the clink

To know when one is well

To laugh and cry both with a breath

To lie at catch

To lie in bed and forecast

To live like fighting cocks

To look through the fingers

To make both ends meet

To make money like hay

To nail to the counter

To nourish a snake in one's bosom

To outface with a card of ten

To pipe in an ivy leaf

To ring noon on one's head

To rule with a rod of iron

To seek a knot in a bulnush

To sell one's birthright

To set the Thames on fire

To shoot Niagara

To sit like a nightingale with a thorn against one's breast

To speak like a parrot

To stink like a polecat

To take a wife down in her wedding shoes

To take to one's heels

To teach the cat the way to the kirn

To turn over the perch

To understand trap

$\begin{array}{llll} & & & \\ 3.53 & 3.00 & 3.87 & 1.37 \\ & & & \\ 4.27 & 4.47 & 4.30 & 1.57 \\ \mathbf{4 . 3 0} & 4.03 & 3.67 & 1.60 \\ & & & \\ 3.40 & 2.90 & 3.63 & 1.30 \\ & & & \\ 5.27 & 5.89 & 4.20 & 1.70 \\ 3.53 & 4.20 & 4.17 & 4.60 \\ 4.63 & 5.33 & 3.50 & 4.03 \\ 2.23 & 2.30 & 3.73 & 2.33 \\ 4.67 & 5.33 & 3.83 & 2.40 \\ 4.43 & 5.30 & 4.23 & 4.37 \\ 4.57 & 5.37 & 4.87 & 4.70 \\ 3.87 & 5.10 & 3.83 & 3.53 \\ 3.20 & 3.90 & 4.13 & 2.80 \\ 3.37 & 3.87 & 4.87 & 3.97 \\ 4.20 & 3.90 & 3.10 & 2.17 \\ 3.63 & 4.37 & 3.73 & 1.90 \\ 2.93 & 3.27 & 2.77 & 1.70 \\ 4.73 & 5.83 & 4.03 & 3.30 \\ 4.13 & 4.23 & 3.90 & 2.80 \\ 3.67 & 3.23 & 2.83 & 1.33 \\ 5.57 & 6.10 & 3.60 & 1.73 \\ 5.03 & 5.87 & 4.20 & 4.47 \\ 5.03 & 5.27 & 2.93 & 2.53 \\ 3.50 & 3.47 & 3.60 & 2.47 \\ 2.17 & 1.83 & 2.93 & 1.20 \\ 4.20 & 5.30 & 4.17 & 2.57 \\ 4.60 & 5.90 & 4.07 & 6.03 \\ 3.40 & 2.07 & 3.10 & 1.17 \\ 3.50 & 4.53 & 2.90 & 1.40 \\ 3.70 & 4.17 & 3.60 & 2.03 \\ 3.87 & 4.73 & 3.20 & 1.47 \\ 5.40 & 6.50 & 5.37 & 6.90 \\ 3.27 & 3.33 & 2.97 & 1.53 \\ 3.20 & 3.10 & 4.27 & 2.57 \\ 4.33 & 4.53 & 4.30 & 2.80 \\ 3.03 & 2.50 & 3.07 & 1.57 \\ 4.10 & 4.30 & 3.80 & 2.20 \\ 4.97 & 5.27 & 2.93 & 1.87 \\ 4.60 & 5.60 & 3.37 & 2.73 \\ 3.97 & 5.33 & 5.10 & 6.37 \\ 4.23 & 5.20 & 4.07 & 2.17 \\ 5.17 & 5.43 & 3.83 & 3.07 \\ 4.03 & 5.67 & 3.33 & 1.60 \\ 3.53 & 3.83 & 3.43 & 1.53 \\ 3.50 & 3.67 & 2.97 & 1.37 \\ 2.87 & 3.27 & 3.27 & 1.47 \\ 5.13 & 5.50 & 4.27 & 4.17 \\ 3.97 & 3.80 & 3.27 & 1.10 \\ 3.23 & 3.60 & 3.47 & 3.80 \\ 4.93 & 5.09 & 3.50 & 1.73 \\ 3.27 & 4.67 & 3.33 & 2.13 \\ & & & \\ 4.17 & 5.00 & 3.57 & 1.77 \\ 5.33 & 5.50 & 3.70 & 2.77 \\ 4.87 & 5.10 & 2.83 & 2.20 \\ 3.87 & 4.63 & 3.63 & 1.37 \\ 4.20 & 4.80 & 4.07 & 3.83 \\ 4.10 & 3.13 & 3.27 & 1.30 \\ 4.00 & 3.97 & 3.23 & 1.93 \\ 3.10 & 2.97 & 3.13 & 1.40\end{array}$


APPENDIX (Continued)

To wind up your bottom

To work double tides

Tomorrow morning I found a horseshoe

Too far east is west

Trouble brings experience and experience brings wisdom

Truth needs no colours

Two heads are better than one, even if the one's a sheep's

Walk, knave, walk!

Water is the eye of a landscape

Water stoups hold no ale

We are all Adam's children but silk makes the difference

We are fools one to another

We know not who lives or dies

We live by laws not by by examples

Welcome when you go

What may be done at any time, will be done at no time

What the fool does in the end, the wise man does at the beginning

What the king wills, that the law wills

What you have to say will keep cold, I warrant

What's a Gentleman but his pleasure

Whatsoever was the father of a disease, an ill diet was the mother

When an ass kicks you, never tell it

When God will punish, he will first take away the understanding

When my ship comes home

When the barn's full, you may thresh before the door

When the devil is a hog. you shall eat bacon

When the devil prays, he has a booty in his eye

When wine sinks, words swim

Where there is no honour, there is no grief

Who builds his house of sallows, and pricks his blind horse over the fallows, and suffers his wife to go seek hallows, is worthy to be hanged in the gallows

Who hastens a glutton chokes him

Whosoever is king, thou wilt be his man

Win at first and lose at last

Wisdom has one foot on land, and another at sea

Wishers and woulders be no good householders

Wite yourself if your wife be with baim

Women naturally deceive, weep and spin

Wonders will never cease

Years know more than books

You are a man among the geese when the gander is away

You cannot eat your cake and have your cake

You cannot get leave to thrive for throng

You have gotten a piece of Kitty Sleitchock's bannock

You look like a Lammermoor lion

You may poke a man's fire after you've known him seven years, but not before

You must ask your neighbour if you shall live in peace

You ride as if you went to fetch the midwife

You try all ways to the wood

You were bred in Brasen-Nose College

You will never be mad, you are of so many minds

You will scratch a beggar one day before you die

Young colts will canter

\begin{tabular}{|c|c|c|c|}
\hline 3.27 & 4.00 & 3.40 & 2.6 \\
\hline 3.00 & 2.93 & 3.47 & 10 \\
\hline 3.57 & 3.93 & 3.87 & \\
\hline 3.97 & 5.03 & 5.50 & \\
\hline 3.73 & 3.57 & 6.03 & \\
\hline 3.63 & 4.33 & 5.73 & \\
\hline 4.80 & 5.40 & 5.03 & \\
\hline 4.27 & 4.30 & 3.47 & \\
\hline 3.73 & 4.63 & 4.23 & 1.2 \\
\hline 4.10 & 3.83 & 3.43 & \\
\hline 3.60 & 3.20 & 3.57 & 1.6 \\
\hline 3.13 & 3.43 & 4.03 & 1 \\
\hline 3.17 & 3.33 & 4.33 & \\
\hline 3.93 & 3.60 & 4.40 & 2.8 \\
\hline 3.10 & 3.27 & 4.07 & \\
\hline 3.23 & 3.13 & 4.60 & 3.0 \\
\hline 3.87 & 3.50 & 3.53 & \\
\hline 3.90 & 3.80 & 5.80 & .8 \\
\hline 2.73 & 2.77 & 3.63 & 1.1 \\
\hline 2.80 & 2.80 & 4.17 &  \\
\hline 3.50 & 3.83 & 3.60 & 1. \\
\hline 4.43 & 4.57 & 4.17 & \\
\hline 2.80 & 3.20 & 3.73 & 10 \\
\hline 4.57 & 5.87 & 4.90 & 5.3 \\
\hline 4.10 & 5.20 & 3.07 & 1.3 \\
\hline 4.47 & 4.53 & 3.67 & \\
\hline 4.50 & 4.33 & 4.00 & 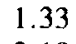 \\
\hline 3.83 & 4.57 & 5.13 & 2.1 \\
\hline 3.57 & 3.50 & 4.27 & 2.3 \\
\hline 4.53 & 4.44 & 3.83 & 1.4 \\
\hline 3.77 & 3.80 & 5.43 & 1.5 \\
\hline 3.83 & 3.53 & 3.90 & 1.6 \\
\hline 2.97 & 3.67 & 3.87 & 2.7 \\
\hline 3.53 & 4.43 & 4.50 & 1.9 \\
\hline 3.13 & 3.57 & 4.03 & 1.5 \\
\hline 2.73 & 2.57 & 3.07 & 1.1 \\
\hline 4.30 & 3.57 & 2.97 & 1.9 \\
\hline 3.03 & 3.83 & 5.70 & 6.5 \\
\hline 3.13 & 3.80 & 5.47 & $?$ \\
\hline 4.03 & 4.93 & 4.03 & 2.1 \\
\hline 4.70 & 5.30 & 4.27 & \\
\hline 2.70 & 2.03 & 2.87 & 1.2 \\
\hline 2.33 & 1.80 & 3.00 & 1.0 \\
\hline 4.00 & 3.33 & 3.27 & 1 \\
\hline 3.80 & 4.27 & 3.77 & 1.3 \\
\hline 3.60 & 3.00 & 4.30 & 1.8 \\
\hline 4.50 & 4.33 & 4.20 & 1.1 \\
\hline 3.13 & 2.90 & 3.67 & 1.5 \\
\hline 2.97 & 2.33 & 2.77 & 1.1 \\
\hline 2.87 & 3.43 & 4.33 & 1.5 \\
\hline 3.93 & 4.27 & 3.40 & 1.5 \\
\hline 5.03 & 4.80 & 4.30 & \\
\hline
\end{tabular}

(Manuscript received January 8, 1992;

revision accepted for publication July 15,1992 ) 